\title{
Analysis on the Concept and Model Structure of College Students' Employment Guidance
}

\author{
Shunyi Luo, Xiaofeng Liu, Chaohong Zhang, Jun Dai
}

Northwest A\&F University, College of Mechanical and Electronic Engineering, Yangling, Shaanxi 712100

Keywords: college student; employment guidance; concept and model

\begin{abstract}
The employment of college graduates has become a more serious problem. There is a problem that employment guidance education and ideological and political education are not well integrated in the employment guidance of college students, the content of employment guidance for students is not perfect, and the employment guidance education method is outdated. Based on the above problems, the paper puts forward the strategy of perfecting the employment guidance of college students, establishing the new concept of employment guidance for college students, including the concept of career development, the whole concept, and the service concept; following the action principle of employment guidance of college students, including the development principle, systematic principles, guiding principles and practical principles.
\end{abstract}

\section{Introduction}

To construct a career guidance concept and practice model for Chinese college students, we can learn from and learn from some of the beneficial results of Western countries. After many years of development and evolution, the employment guidance of college students in western countries has formed a concept and practice model that promotes the comprehensive, coordinated and sustainable development of college students. After careful study and deep rational thinking on the employment guidance of college students in China, we found that many people have a superficial understanding of the concept of employment guidance, and the original function development is single, still in the stage of spontaneous exploration, unable to meet the requirements of college students and society, and become One of the "bottleneck" factors that restrict the development of higher education. Therefore, learning and drawing on the ideas and practical modes of employment guidance for Western college students is of great significance to the employment guidance of college students with Chinese characteristics.

\section{Definition of Employment Guidance for College Students}

The relevant theory for employment guidance was first proposed by the United States. The main source is the employment-related employment guidance theory proposed by Parsons. Based on the related theories of psychology and humanism, Super.DE and Rogers completed the transformation of employment guidance to career guidance, and became an important theoretical basis for the employment guidance of college students in western countries. . Employment guidance is also called "job-seeking career guidance”, "career guidance” or "vocational counseling”, and there is a narrow and broad distinction in definition. "The narrow employment guidance is mainly to provide relevant employment information to relevant employees and help the employed to make employment choices, mainly as a mediator role for specific occupations and job seekers. The broad employment guidance mainly refers to the relevant job seekers. The development characteristics and related willingness are the main preconditions to help students establish a correct employment and career choices, provide a way to choose different occupations, acquire more professional knowledge, and introduce talents with different academic qualifications for the broad labor market. "8 Undoubtedly, for college students, employment guidance is mainly referred to the broad employment guidance. The employment guidance of college students mainly refers to the ability to provide employment for the majority of college students. It is generally reflected in the relevant 
guidance of college students' employment trends, the general training of employment quality and the continuous training of employability. The necessary employment guidance for college students can help college students to develop employment and the ability to survive in society. It can not only help the majority of college students to find employment, but also continuously improve their overall quality and obtain more employment guidance. Service delivery channels have a direct impact on the ability of college graduates and are an important stage in the employment of college graduates.

\section{The Value of Employment Guidance for College Students}

College students as the reserve army of high-quality talents in China, the comprehensive development of college students is the core appeal of education. Among the factors for the overall development of college students, this should include career planning, employment concepts and ideals, employment value orientation, and professional ethics that affect their life. However, the current employment guidance is seriously lacking a high degree of comprehensive consideration and lack of overall overall arrangement. Some of the conditions necessary for the employment of college students, such as employment ability training, professional judgment, career planning and professional ethics, are obviously weak. In the current employment situation, in order to meet the requirements of employers, the employment guidance of college students as one of the dimensions of students' all-round development will surely achieve good results. The objective requirements of the market economy system for talents. China is in the stage of full implementation of the market economy. Under this market-oriented market employment pattern, units and enterprises rationally allocate talents according to market rules and select college students as a key production factor. Under the conditions of innovation, according to the laws of the market, the employment guidance of college students can train and guide the employment of college students, so that the college students they cultivate can meet the objective requirements of the market economy. Therefore, the employment guidance of innovative college students is an objective requirement of the laws of market economy.

\section{Ideas and Methods to Innovate College Students' Employment Guidance}

Our country is in the age of reform. All social reforms are inseparable from the cultivation of innovative talents, and in the cultivation of innovative talents, innovative education plays a key role. As an important part of higher education, college students' employment guidance needs innovation. From the current situation of employment guidance for college students in China, it can be clearly seen that the current concept of employment guidance for college students in China is quite backward. Therefore, the concept and method of innovative employment guidance for college students is the current urgent task.

People-oriented employment guidance concept for college students. The employment guidance of college students is a systematic and complicated work, which is a very important content for colleges and universities to serve students. However, the facts show that most universities in China are still at a low level of service. The level of theory, personnel attitude, work procedures, efficiency, etc. are not recognized by students. The institutions that serve the students themselves have serious administrative-oriented thinking. The fragmentary events that occur in the employment process of college students cannot be solved in time. As a base of high-quality talents, colleges and universities receive the humanized service they deserve. This is what the whole society expects, and it also leaves a good ideological education for students to leave the school. Therefore, the employment guidance of college students urgently needs to change the concept, and should be student-centered and truly people-oriented.

Some educators pointed out: "Education is more than just for employment." The task of talent cultivation is the task that colleges and universities shoulder. Colleges and universities should change their concepts to take college students' employment guidance as an important part of cultivating talents and carry out a new battlefield for quality education. In addition to helping 
students to "full employment", employment guidance should be used to develop students' potential and to promote students to form a correct career outlook, professional ethics, and professional self-evaluation. In short, the employment guidance of college students should be an important way to cultivate talents. It is a misunderstanding of the current purely instrumentalization of employment guidance, and practical employment guidance is an important way of talent training system.

The cultivation process is complete. The whole process of the so-called training process means that the employment guidance of college students should run through the entire university education stage. In this process, graduates should have different plans from the time they enter the university. According to the employment guidance experience and theory of foreign university students, soon after the new students enter school, they must make a specific plan for their future careers and prepare for university life as a whole. The content of job search skills runs through the usual employment guidance classes.

The so-called full-scale training objectives mean that the employment guidance should be transformed from the "employment resettlement" stage of the division to the cultivation of talents. The current employment guidance only stays at the policy of helping students find jobs. However, according to the results of recent years, the changes in China's employment policy have led to the current employment guidance is still at an initial level. Therefore, colleges and universities should adjust the goal of employment guidance to a long-term, full-program talent training process. Only in this way, under the same conditions, under the unfavorable objective conditions of eliminating employment, etc., as a career guidance for talent training mode It will surely achieve long-term and considerable results. At present, colleges and universities in China still regard "college employment guidance" as "graduate employment guidance." This kind of mistake led to the failure of employment guidance. This narrowing of the concept of employment guidance for college students has seriously affected the effectiveness and mode of employment guidance. The purpose of the employment guidance of college students is to cover all college students. The employment guidance of graduates is regarded as the employment guidance of college students, and they face bankruptcy under the current employment situation. Only graduates who carry out employment guidance can't achieve the desired results in both time and long-term planning. The four years of college majors are completely decoupled from career planning, and most students face confusion. Therefore, the target of employment guidance for college students should include all college students, and form a career guidance for the whole process of training.

Professional guidance is the development trend of international career guidance. It includes both the professionalization of employment guidance content and the professionalization of the employment guidance team. After all, teachers are the key. Without the professionalization of teachers, there will be no specialization in employment guidance. Specialization has become an important trend in the development of social career, and professionalism has become an important indicator to measure professional maturity. Specialized teachers are often trained in long-term professional training and systematic professional ethics. They have deep and unique expertise and technology, have a high sense of social responsibility and service, are rich in affinity, appeal and attractiveness. The knowledge, personality, and talents can help students, and they have a strong natural influence on college students. Employment guidance has great reliability and validity, and is welcomed by college students. At present, most of the employment guidance teachers in colleges and universities are appointed by the administrative cadres appointed by the organization. They have the characteristics of job-based and are obedient. They do not have systematic professional training, lack basic knowledge of employment guidance and various skills, often with their own power. Sexual influence to tutor students, pay attention to the power standard, despise the ability standard, employment guidance does not meet the individualized and humanized characteristics of college students, lack of credibility and validity, so employment guidance has become a "fit" in these schools. To the psychological soothing effect. It can be seen that the low level of professionalism of employment guidance teachers is the "bottleneck" factor that restricts the development of employment guidance. Only strengthening the training of teachers under the existing conditions is the key to improving the professional level of teachers, and it is also a 
priority. . We draw on the training content of professional professional instructors in the United States. The employment instructors must have the ability and knowledge of ten aspects:! Career development theory: The theoretical foundation and knowledge are the basic quality requirements for professional guidance and development of professionals; "Persons and groups Mentoring skills: Individual and group coaching skills are essential for effective career guidance; Individual and group assessment skills are necessary for professional instructors to conduct career guidance; \$nformation and Resources: Information and Resource Basis and Knowledge It is a necessary condition for professional guidance.

\section{Conclusion}

The employment guidance of college students should be one of the important ways to train talents in colleges and universities. There are many ways and means to train talents in colleges and universities. The employment guidance of college students has been excluded from the way of talent cultivation. It is only a short-term benefit tool for college graduates to find jobs. . At present, the cultivation of talents in colleges and universities generally includes professional education, practical education, and ideological and moral education. With the reform of the education system and the change of the employment mode of college students, the cultivation of talents in China has shifted from elite education to popular education. College students have become the product of the prospective job search team. If the employment guidance of college students has been stuck in the era of elite education only as a job-seeking skill, the shallow level of employment information collection clearly deviates from the law of education development.

\section{References}

[1] Chen Deming. Research on the Combined Mechanism of College Employment Guidance Courses [J]. School Party Construction and Ideological Education, 2010(13).

[2] LIN Haifeng. Research and Practice of College Students' Entrepreneurship Education and Talent Cultivation [J]. Continuing Education Research, 2011(10).

[3] Chen Chong. Analysis of College Career Education under the Background of College Students' Employment Difficulties [J]. Educational Development Research, 2012(Z1).

[4] Wei Qiaoyuan, Wei Wenrong. On the Career Guidance of College Graduates_-Taking Guangxi National Teachers College as an Example [J]. Education Exploration, 2011(7). 